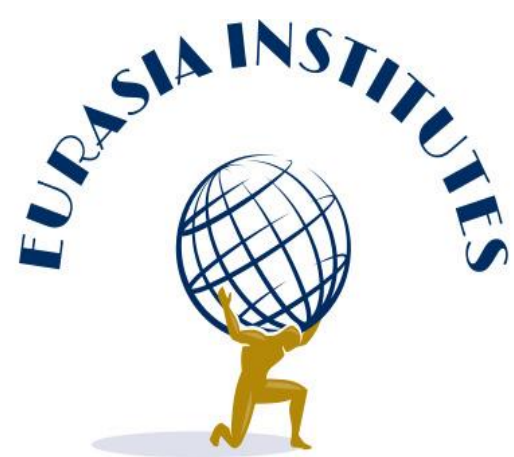

DOI: 10.47669/PSPRP-6-2020

What Has Changed in Uzbekistan? Explaining Post-Karimov State-Building

Aram Terzyan

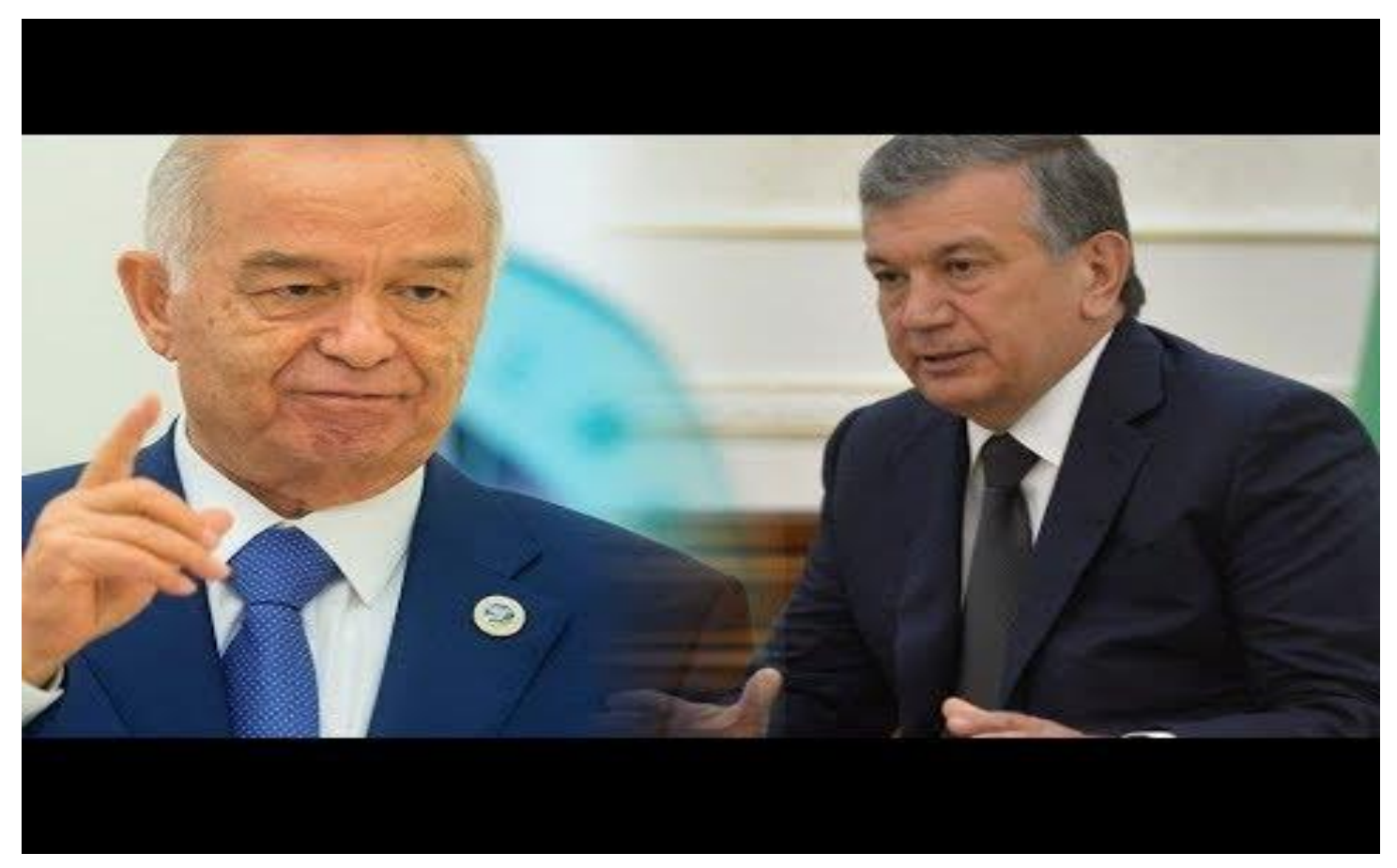

Center for Central Asian Studies

Post-Soviet Politics Research Papers

$6 / 2020$ 


\begin{abstract}
This paper explores the economic and political dimensions of post-Karimov statebuilding in Uzbekistan. It suggests that while Shavkat Mirziyoyev's reform agenda has led to considerable economic reforms, the country's political system, plagued with a myriad of authoritarian malpractices has largely remained untouched. In effect, Uzbekistan remains inherently authoritarian, with lack of a robust opposition and civil society. It concludes that the depth and sustainability of Uzbekistan's economic reforms considerably depend on broader democratic reforms, including the fight against corruption and advancement of a vibrant civil society.
\end{abstract}

Keywords: Uzbekistan, leadership change, authoritarian legacy, economic transformation.

\title{
Introduction
}

With Shavkat Mirziyoyev's rise to power in 2016 following Islam Karimov's death, Uzbekistan has seen first leadership change since 1989. Karimov's Uzbekistan was a state with remarkable internal stability and a high degree of economic autarchy and was regarded as one of the world's most repressive (Schmitz, 2020). Unlike neighbors such as Kazakhstan, Uzbekistan avoided economic liberalization following the break-up of the Soviet Union, while retaining the core characteristics of the centrally planned economy (Ibid).

As a matter of fact, regime insider Shavkat Mirziyoyev has been ambitious in terms of undertaking reforms without provoking destabilization. His reform agenda has specifically targeted economic liberalization, while leaving the political system, plagued with a series of authoritarian malpractices largely untouched.

Several commentators would express skepticism over the feasibility of fundamental reforms in post-Karimov Uzbekistan, while contending that the new President would be bound by Karimov's authoritarian legacy and practices (Abdurasulov, 2016). Such contentions are unsurprising, given that Mirziyoyev had been the Prime Minister of Uzbekistan since 2003 under Karimov's presidency and gained a reputation of a person who "gets the job done" (Lemon, 2019, p. 2).

Alternatively, other students would be more optimistic about Mirziyoyev's reform agenda, by suggesting that he would distance himself from Karmiov's malpractices and put the country on the path to economic and political reforms (Avci, 2018; Aydin, 2017).

Notably, some commentators suggest, the fact that Mirzyioev was not part of the Soviet elite structure and did not benefit from this system through corruption influenced his decision to reform the persisting system (Blackmon, 2020). 


\section{What Has Changed in Uzbekistan? Explaining Post-Karimov State-Building}

To bring clarity to the ongoing debates, this study addresses the following research question: What are the core economic and political outcomes of post-Karimov state-building in Uzbekistan?

This paper is an in-depth case analysis, that uses policy analysis and process tracing to examine the core dynamics of post-Karimov state-building in Uzbekistan.

\section{The implications of the first post-Soviet leadership change in Uzbekistan: Main perspectives}

Shavkat Mirziyoyev's rise to power represents a novel development in the post-Soviet space. Inheriting a country, plagued with a myriad of authoritarian practices, including centralization of power and state repression, Mirziyoyev adopted a reform agenda focused on economic and broader governance reforms. Specifically, Mirziyoyev's government adopted the Development Strategy 2017-2021, targeting the following key areas: improvement of state and social construction; the rule of law and further reform of the judicial system, aimed at strengthening the real independence of the judiciary and guarantees protection of the rights and freedoms of citizens; development and economic liberalization aimed at further strengthening the macroeconomic stability and the maintenance of high economic growth (Decree of the President of the Republic of Uzbekistan, 2017).

Starr (2018) details five primary initiatives designed to improve the lives of people in the rural community: increasing investment in the rural sector; improving working conditions for laborers, including addressing the problem of child labor; creating initiatives to restore the Aral Sea; modernizing rural life through construction of more affordable and adequate housing; and finally, addressing the problem of adequate financing so that commercial banks could provide loans to small and medium-sized businesses (Blackmon, 2020, p. 9).

In terms of the economic implications of the leadership change in Uzbekistan, it is noteworthy that by 2019, Mirziyoyev's economic reforms led The Economist to name Uzbekistan its "country of the year" (Zakirov, 2020). Overstepping Karimov's "Uzbek Model", Mirziyoyev has taken strides towards integrating the country into the global economy through finance and trade. Unlike Karimov's preference for a Soviet style statedominated economy, Mirziyoyev has been striving to make the economy more efficient by introducing a market mechanism while attracting foreign investment (Ibid). Remarkably, according to 2018 Doing Business report, Uzbekistan became 'the regional leader in the total 
number of reforms in the Europe and Central Asia region and [was] among the ten economies improving most in 2016-2017' (World Bank, 2017). Similarly, 2020 Doing Business report suggests that the business climate in Uzbekistan has considerably improved, making the country one of the world's top twenty most improved economies for ease of doing business. The report noted that the country had moved up the rankings to 69th out of 190 countries thanks to reforms in four key areas: tax payments, minority investor protections, cross-border trade, contract enforcement (Doing Business, 2020).

The ongoing reforms in Uzbekistan have been welcomed by the international community, with the US Commerce Secretary extoling the promising outputs of "successful political and democratic reforms that are underway" in Uzbekistan (U.S. Department of Commerce, 2019). Against this backdrop, some students point to the fact that the main rationale behind the reforms is economic modernization of the country, rather than its political liberalization (Putz, 2018).

Some observers have employed the notion of "authoritarian modernization" to describe the nature of transformations in Uzbekistan (Anceschi, 2018). Namely, Luca Anceschi (2019) argues, that the changes occurring in Uzbekistan should be put in the framework of authoritarian modernization rather than that of democratization. It follows, that the reforms in Uzbekistan come down to upgrading local authoritarian practices rather than to liberalizing its political landscape (Anceschi, 2019).

Similarly, the notion of "authoritarian upgrading" has been used to describe the changes in Uzbekistan (Schiek, 2018). Lemon (2019) suggests that, the "authoritarian upgrading" in Uzbekistan features four strategies. First, Mirziyoyev has implemented market-oriented economic reforms, allowing the ruling elite to capture many of these benefits. Second, he has purged the old elite, bringing in new technocrats to improve efficiency. Third, he has moved from a system that views the population as a threat requiring constant discipline towards one that manages society through looser regulations and new incentives. Fourth, he has strengthened and diversified Uzbekistan's external ties (Lemon, 2019).

Clearly, while the focus of modernization is put on economy, the political shortcomings remain unaddressed. That said, unlike political reforms, the economic ones are more tangible (Ünal, 2018). The vivid illustration is non-existent party system. The five parliament parties - Erk, Birlik, the Fatherland Progress party, Adolat (Social Democratic Party), the People's Democratic Party, Party of National Revival, and the National Democratic Party Fidorkorlar that would consistently support Karimov, nowadays support Mirziyoyev (Bowyer, 2018). 
In line with Kazakhstan, Uzbekistan appears to adhere to "economy first, politics later" approach (Anceschi, 2019, pp. 111-112).

Overall, while Mirziyoyev's ambitious reform agenda has sparked a wave of optimistic commentaries about its positive implications for country's economic transformation and modernization, the depth and sustainability of Uzbekistan's economic reforms considerably depend on broader governance reforms, including the fight against corruption.

Mirziyoyev's presidency has been conducive to improving country's human rights record, with the Uzbek authorities shutting down the notorious Jaslyk prison and lifting ban on several critical websites. Nevertheless, the government remains inherently authoritarian with its heavy reliance on security services - retaining vast power to suppress dissent and pluralism (Human Rights Watch, 2019).

Ambrosio (2015) aptly notes that, post-USSR political evolution in Central Asia has shown that regimes are not just the ruler. Rather, it is a whole system with formal and informal rules (Ambrosio, 2015).

Indeed, as suggested by subsequent sections, there is a whole bunch of obstacles to fundamental democratic reforms in Uzbekistan, including but not limited to underdevelopment of the middle class, the robust authoritarian legacy, compounded by limited reach of external democratic centers, as well as low living standards of the population and lack of a vibrant civil society.

\section{Lack of a vibrant civil society}

Civil society in Uzbekistan has been primarily associated with mahallas, which are selfgoverning bodies responsible for helping members of the community and other social work (conflict resolution, overall community upkeep, etc.). Essentially, one of the main priorities on the path to a vibrant civil society emergence in Uzbekistan includes developing the capacities of NGOs, particularly secular civil society organizations. Even though there are over 9000 NGOs registered in Uzbekistan, unlike conservative religious organizations, the opportunities for secular civil society organizations to represent societal interests remain limited due to their organizational weakness and lack of financial support (Khamldova, 2018). As a result, many of them have long been inactive with little to no potential to represent certain interest groups and influence decision making. 
Studies show that one of the main dimensions on the path to a vibrant and consolidated civil society is the "change on the inside", related to the nature of civil society per se: such as the way it is organized and operates. This has a great deal to do with the development of adequate institutional and professional capacity in civil society organizations and networks as a vital tool for influencing policy making (Terzyan, 2020a). The institutional development at the organizational level includes building organizational capacities for governance, decision-making, and conflict management, as well as clarifying organizational identity, values, and strategy of impact. The latter is of crucial relevance as a lot of CSOs in Uzbekistan were established with no predefined mission, strategic plans, and organization structure. That said, they were doomed to failure in terms of addressing the specific needs of their constituencies.

Another formidable challenge to civil society advancement is restrictive environment, compounded by state repression of dissent and pluralism, along with severely limited freedom of expression. Karimov's administration would meticulously control media narrative on politically sensitive issues in Uzbekistan, while shuttering or blocking independent outlets (Freedom House, 2020). Even though domestic media, including news websites and live television programs, now cautiously discuss social problems and even criticize local officials, it is not uncommon for journalist to practice self-censorship to avoid harassment by government. As a result, they refrain from openly criticizing Mirziyoyev and the government (Freedom House, 2020). Not surprisingly, as suggested by Human Rights Watch reports, censorship is still widespread in Uzbekistan, with the authorities consistently restricting the media through the official state bodies that issue registration for media outlets and regulate journalistic activity (Human Rights Watch, 2019).

Along with the restrictive legislation, low trust, and misperceptions of civil society organizations, have significantly obstructed the advancement of a vibrant civil society in Uzbekistan. It has been common for post-Soviet societies to treat civic associations as threat to the power and stability of the state together with the conviction that the state bears the responsibility for the wellbeing of the society (Terzyan, 2020a).

As a matter of fact, establishing a civil society platform for NGOs, and media organizations to monitor government activity is essential for the emergence of a vibrant civil society. In the past two years, Uzbekistan has introduced several reforms and amended legislation, but there has been no analysis or monitoring of their implementation or potential or real impact on society (Khamldova, 2018). Meanwhile, the input from NGOs, 
think tanks and media can significantly contribute to the implementation of those state programs that are deemed useful by civil society. This, in turn, comes down to the changes in the very nature of civil society relations with the state and its potential and ability to foster reform, or what is often referred to as "change on the outside." This has a lot to do with increasing their impact on public policy, through intensifying their interaction with public institutions and actors and most importantly, through engaging more with their constituencies (Terzyan, 2020a).

A major impediment to civil society advancement in Uzbekistan is prevailing postSoviet "informality" in the form of behavioral practices, such as considerable tolerance towards informal governance, the use of informal networks and connections in exchanges of favors, phone justice, corruption, etc.

Moreover, the rise of 'illiberal civil society' or movements with a conservative agenda is a common phenomenon across Central Asia, and elsewhere. In Central Asia, Russianlanguage media, and religious-based outlets, have become instruments to spread illiberal ideas, which use 'traditional family values' and 'national identity' to condemn progress, often related to the rights of LGBT, the role of women in society or different minorities.

Overall, the core hindrances to the advancement of a vibrant civil society in Uzbekistan include the restrictions imposed on freedom of expression and association, as well as the Uzbek government's tendency of silencing dissent. Meanwhile, eradicating these malpractices is critical to reassuring and reinforcing Mirziyoyev government's promises and pledges of significant democratic reforms.

\section{Fighting corruption}

Corruption has long condemned Uzbekistan to a vicious circle of underdevelopment, bad governance and inability to implement reforms. While the newly elected president has taken anti-corruption measures, including the Law "On Anti-Corruption" that established a legal framework in the fight against corruption, the results are still negligible (OECD 2019).

Uzbekistan is the 153 least corrupt nation out of 180 countries, according to the 2019 Corruption Perceptions Index reported by Transparency International (Transparency International, 2020). The potentially susceptible areas to corruption include civil service, the system of asset and interest declaration by civil servants, judiciary, prosecutorial authorities, etc. Judiciary is of paramount importance, given that judicial independence and integrity are 
critical to ensuring the enforcement of the anti-corruption reforms in other spheres (OECD, 2019, pp. 9-12).

Mirziyoyev's anti-corruption policy has targeted former corrupt officials, some of which have been convicted of corruption. Namely, on February 25, 2020 Uzbekistan's Supreme Court announced that Ikhtyor Abdullaev, the former chief of Uzbekistan's State Security Service, was sentenced to 18 years in prison after being found guilty of organizing a criminal group, bribe-taking, abuse of office, extortion, the theft of private property, violating customs regulations, and other crimes (Radio Liberty, 2020). Similarly, former Prosecutor-General Otabek Murodov was found guilty of bribe-taking and sentenced to five years of freedom limitation. Moreover, Seven other defendants in the case, including former subordinates of Murodov and Abdullaev, were sentenced to prison terms of between 5 years and 17 years, with a dozen other defendants receiving sentences that did not include jail time (Radio Liberty, 2020).

The 2019 OECD report notes a growing interest in anti-corruption studies in Uzbekistan. Lots of surveys have been carried out at the national level and across different sectors with the publication of their results. However, it is important that such surveys be more actively applied in the development of anti-corruption policies and their impact assessment (OECD, 2019). Nevertheless, as indicated in the Freedom House Report (2020), since Karimov's death the media coverage of corruption has increased significantly, however in some cases the journalists who voice their concerns are more likely to experience more pressure than the corrupt officials themselves (Freedom House, 2020).

One of the biggest challenges of anti-corruption reforms in Uzbekistan is the persistence and prevalence of corrupt practices by political and economic elites. Clearly, the political elite's robust commitment to eradicating systemic corruption is indispensable. Meanwhile, inconsistencies and the weakness of a commitment lead to a situation, where under the banner of "zero tolerance for corruption" governments keep playing a "tolerant corruption" game. The lessons from the successful anti-corruption crusades of Singapore and Hong Kong show the need for anti-corruption reform initiatives to be participatory and inclusive of all stakeholders, including the public and private sectors as well as civil society (Terzyan, 2020b). It is therefore essential for Uzbek civil society organizations to further develop institutional and professional capacity to contribute to anti-corruption reforms and influence their implementation. 


\section{Conclusions}

This paper contributes to the existing literature and ongoing debate regarding the challenges and opportunities of post-Karimov state - building in Uzbekistan. Based on the previous discussion, there are three main concluding observations to make regarding the implications of leadership change in Uzbekistan.

First and in terms of economic implications of the domestic change, overstepping Karimov's “Uzbek Model”, Mirziyoyev has taken strides towards integrating the country into the global economy through finance and trade. Unlike Karimov's preference for a Soviet style state-dominated economy, Mirziyoyev has been striving to make the economy more efficient by introducing a market mechanism while attracting foreign investment. As a result, the business climate in Uzbekistan has considerably improved, making the country one of the world's top twenty most improved economies for ease of doing business. Mirziyoyev'a administration has carried out significant reforms in four key areas: tax payments, minority investor protections, cross-border trade, contract enforcement. Overall, while Mirziyoyev's ambitious reform agenda has sparked a wave of optimistic commentaries about its positive implications for country's economic transformation and modernization, the depth and sustainability of Uzbekistan's economic reforms considerably depend on broader governance reforms, including the fight against corruption.

Second and in terms of broader democratic reforms, Miriyoyev's administration has not achieved considerable accomplishments in terms of overcoming Karimov's authoritarian legacy. It remains inherently authoritarian with lack of a vibrant civil society and a robust political opposition. The restrictive environment compounded by state repression of dissent and pluralism in Uzbekistan remains a major hindrance to the advancement of a vibrant civil society. In effect, while adopting an ambitious agenda focused on economic reforms, Miriyoyev's administration has left the political system, plauged with a series of authoritarian malpractices largely untouched.

Last, but not least, Mirziyoyev's administration has taken strides towards fighting rampant corruption. The anti-corruption policy has targeted former corrupt officials, some of which have been convicted of corruption. One of the biggest challenges of anti-corruption reforms in Uzbekistan is the persistence and prevalence of corrupt practices by political and economic elites. Meanwhile, the lessons from the successful anti-corruption crusades of 
Singapore and Hong Kong show the need for anti-corruption reform initiatives to be participatory and inclusive of all stakeholders, including the public and private sectors as well as civil society. It is therefore essential for Uzbek civil society organizations to further develop institutional and professional capacity to contribute to anti-corruption reforms and influence their implementation.

\section{References}

Abdurasulov, A. (2016). Intrigue and power games as Uzbek leader ails. Retrieved September 13, 2020 from https://www.bbc.com/news/world-asia-37241645.

Ambrosio, T. (2015). Leadership succession in Kazakhstan and Uzbekistan: Regime survival after Nazarbayev and Karimov. Journal of Balkan and Near Eastern Studies, 17(1), pp. 49-67.

Anceschi, L. (2018). Modernising Authoritarianism in Uzbekistan. Retrieved September 8, 2020 from https://www.opendemocracy.net/en/odr/modernisingauthoritarianism-in-uzbekistan/.

Anceschi, L. (2019). New Authoritarianism in Post-Karimov Uzbekistan. Monitoring Central Asia and the Caspian Area. Retrieved September 8, 2020 from http://www.oacc.ieaexport.eu/cgi-bin/allegati/94899497-25d8-4ac5-9b30-

b48800e6e586_Monitoring\%20Central\%20Asia\%20and\%20the\%20Caspian\%20Area.\%20 Development\%20Policies, \%20Regiona1\%20Trends,\%20and\%20the\%20Italian\%20Interest s.\%20pdf.pdf\#page $=108$.

Avc1, E. (2018). Değişen dünyada değişen Özbekistan. Bilgesam. Retrieved September 19, 2020 from http://www.bilgesam.org/Images/Dokumanlar/0-486-2018022161380.pdf.

Aydın, G. (2017). Mirziyoyev's first year in presidency: Any hope for change. Current Debates International Relations \& Law, 4, pp. 99-114.

Blackmon, P. (2020). After Karimov and Nazarbayev: change in Uzbekistan and Kazakhstan? Central Asian Survey, pp. 1-18.

Bowyer, A. C. (2018). Political reform in Mirziyoyev's Uzbekistan: Elections, political parties, and civil society. Central Asia-Caucasus Institute Silk Road Studies Program. Retrieved September 19, 2020 from https://isdp.eu/content/uploads/2018/03/PoliticalReform-in-Mirziyoyev\%E2\%80\%99s-Uzbekistan-A.-Bowyer.pdf.

Decree of the President of the Republic of Uzbekistan (2017). No. UP-4947. On the Strategy for Further Development of the Republic of Uzbekistan. Retrieved September 19, 2020 from https://www.lex.uz/docs/3107042. 
What Has Changed in Uzbekistan? Explaining Post-Karimov State-Building

Doing Business (2020). Doing Business Economy Profile 2020: Uzbekistan. Retrieved September 14 , 2020 from https://www.doingbusiness.org/content/dam/doingBusiness/country/u/uzbekistan/UZB.pdf .

Freedom House (2020). Nations in Transit 2020. Uzbekistan. Retrieved September 9, 2020, from https://freedomhouse.org/country/uzbekistan/nations-transit/2020.

Gürhan, Ü. N. A. L. (2019). State-Building Process in Uzbekistan: Many Miles to Go. Mehmet Akif Ersoy Üniversitesi İktisadi ve İdari Bilimler Fakültesi Dergisi, 5(3), pp. 519-537.

Higgins, A. (2018). As Authoritarianism Spreads, Uzbekistan Goes the Other Way. $\begin{array}{llll}\text { Retrieved } & \text { September } & 18, & \text { from }\end{array}$ https://www.nytimes.com/2018/04/01/world/asia/uzbekistan-reform.html.

Human Rights Watch (2019). Charting Progress in Mirziyoyev's Uzbekistan. Retrieved September 13, 2020 from https://www.hrw.org/news/2019/10/07/chartingprogress-mirziyoyevs-uzbekistan .

Khamldova, S. (2018). Civil society in Uzbekistan: Building from the ground up, EUCAM Retrieved September 15, 2020from https://eucentralasia.eu/2018/07/civil-societyin-uzbekistan-building-from-the-ground-up/ .

Lemon, E. (2019). Mirziyioyev's Uzbekistan; Democratization or Authoritarian Upgradeing. Foreign Policy Research Institute, Eurasia Program, Central Asia Papers June.

Ministry of Justice of the Federal Republic of Uzbekistan. (2019). How to register an NGO through the e-services portal e-ngo.uz. (Как зарегистрировать ННО через портал электронных услуг е-ngo.uz). Retrieved September 13, 2020 from https://www.minjust.uz/ru/press-center/news/98569/.

OECD (2019). Anti-Corruption Reforms in Uzbekistan. Retrieved September 18, 2020 from https://www.oecd.org/corruption/acn/OECD-ACN-Uzbekistan-4thRound_Monitoring-Report-2019-ENG.pdf .

Putz, C. (2018). US Commerce Secretary Praises Uzbekistan's Progress. Retrieved September 18, 2020 from https://thediplomat.com/2018/10/us-commerce-secretary-praisesuzbekistans-progress/ . 
Radio Liberty (2020). Two Top Former Uzbek Officials Convicted on Corruption Charges. Retrieved September 14, 2020 from https://www.rferl.org/a/two-top-ex-uzbekofficials-convicted-corruption/30453695.html .

Schiek, S. (2018). Uzbekistan's Transformation from an "Old" to an "Upgraded" Autocracy. L'Europe en Formation, (1), pp. 87-103.

Schmitz, A. (2020). Uzbekistan's transformation: strategies and perspectives. Retrieved September 19 , 2020 from https://scholar.google.com/scholar?hl=en\&as_sdt=0\%2C5\&q=Schmitz\%2C+A.+\%282020 $\% 29 .+$ Uzbekistan\%E2\%80\%99s+Transformation+Strategies+and+Perspectives.+Stiftung+ Wissenschaft+und+Politik+German\&btnG $=$.

Terzyan, A. (2020a). Towards a vibrant civil society in Ukraine and Armenia. Emerging Europe. Retrieved September 13, 2020 from https://emergingeurope.com/voices/towards-a-vibrant-civil-society-in-ukraine-and-armenia/ .

Terzyan, A. (2020b). Fighting corruption in Ukraine and Armenia. Retrieved September 13, 2020 from https://emerging-europe.com/voices/fighting-corruption-inukraine-and-armenia/ .

Transparency International (2020). Uzbekistan. Retrieved September 19, 2020 from https://www.transparency.org/en/countries/uzbekistan.

U.S. Department of Commerce (2019). Remarks by Commerce Secretary Wilbur L. Ross at the American-Uzbekistan Chamber of Commerce Annual Business Forum. Retrieved September 18, 2020 from https://www.commerce.gov/news/speeches/2019/10/remarkscommerce-secretary-wilbur-1-ross-american-uzbekistan-chamber-commerce.

World Bank (2017). Doing Business Economy Profile 2017: Uzbekistan. Retrieved November 23 , 2020 from https://openknowledge.worldbank.org/handle/10986/25644?show=full.

Zakirov, B. (2020). Can Mirziyoyev's Reforms Bring About a Real Free Market Economy in Uzbekistan? The Diplomat. Retrieved September 13, 2020 from https://thediplomat.com/2020/05/can-mirziyoyevs-reforms-bring-about-a-real-free-marketeconomy-in-uzbekistan/.

Ziegler, C.E. (2016). Introduction, Central Asian Survey, 35(4), pp. 473-480. 